\title{
PLANT GROWTH REGULATORS AND SHADE ON EMERGENCE IN MACADAMIA NUT TREE
}

\author{
REGULADORES VEGETAIS E SOMBREAMENTO NA EMERGÊNCIA DE \\ PLÂNTULAS DE MACADÂMIA
}

\section{Renata Cristina Berchol da Silva GARBELINI' ${ }^{1}$ Elizabeth Orika ONO²; João Domingos RODRIGUES ${ }^{2}$; Elisangela Clarete CAMILI ${ }^{3}$; Antonio Renan Berchol da SILVA ${ }^{3}$}

1. Bióloga, Doutora, Egressa do Programa de Pós-Graduação em Ciências Biológicas (Botânica) Universidade Estadual Paulista "Júlio de Mesquita Filho" - UNESP, Campus de Botucatu, SP, Brasil. renatagarbelini@ hotmail.com; 2. Professores, Doutores, Universidade Estadual Paulista "Júlio de Mesquita Filho" - UNESP, Campus de Botucatu, SP, Brasil; 3. Professores, Doutores, Universidade Federal de Mato Grosso - UFMT, Campus de Cuiabá, MT, Brasil.

\begin{abstract}
This study aimed to evaluate the effect of plant growth regulators and shading on seed germination of macadamia nut trees. The experiment was conducted in a seedling production nursery of the company "QueenNut Macadâmia" located in the "Palmeiras" Farm, Dois Córregos, São Paulo (SP) state, Brazil. The Treatments were T1: water (control) under a shading screen, T2: GA $4+7+\mathrm{N}-\left(\right.$ phenylmethyl)-aminopurine (Promalin $\left.{ }^{\circledR}\right)$ at $200 \mathrm{~mL} \mathrm{~L}^{-1}$ under a shading screen, T3: Promalin ${ }^{\circledR}$ at $400 \mathrm{~mL} \mathrm{~L}^{-1}$ under a shading screen, T4: gibberellic acid $\left(\mathrm{GA}_{3}\right)+\mathrm{kinetin}(\mathrm{Kt})+3-$ indolebutyric acid (IBA) - Stimulate ${ }^{\circledR}$ at $5 \mathrm{~mL} \mathrm{~kg}^{-1}$ seeds under a shading screen, T5: Stimulate ${ }^{\circledR}$ at $10 \mathrm{~mL} \mathrm{~kg}^{-1}$ of seeds under a shading screen, and T6: water (control) under no shading screen. Seeds were soaked in the solutions or in water containing plant growth regulators for 24 hours. Then, they were dried and sown in sand. 450 seeds were used for each treatment. The evaluations began from seedling emergence by counting the total number of seedlings per treatment. A high average of macadamia nut tree seedling emergence was obtained in the treatments $\mathrm{GA}_{4+7}+\mathrm{N}$-(phenylmethyl)-aminopurine (Promalin $^{\circledR}$ ) $400 \mathrm{~mL} \mathrm{~L}^{-1}$ with Sombrite ${ }^{\circledR}(75.7 \%)$, GA $4+7+\mathrm{N}$-(phenylmethyl)-aminopurine (Promalin $\left.{ }^{\circledR}\right) 200 \mathrm{~mL} \mathrm{~L}^{-1}$ (72.6\%) Sombrite ${ }^{\circledR}$ and water (control) without Sombrite ${ }^{\circledR}(71.5 \%)$.
\end{abstract}

KEYWORDS: Macadamia integrifolia. Gibberellins. Cytikinins.

\section{INTRODUCTION}

The macadamia nut is native species from Australia. It belongs to the family Proteaceae. Among the ten species of the genus Macadamia, which produces edible nuts, the species with the highest quality is Macadamia integrifolia (BITTENCOURT, 1965).

Macadamia was brought to Brazil in 1935 to the region of Limeira, São Paulo state, by Dierberger. The production of seedlings for sale thus began (DIERBERGE; MARINO NETO, 1985).

Due to a good adaptation and the production of commercially valuable nuts, macadamia has a great production potential to São Paulo and national agriculture (OJIMA, 1983).

Brazil is the fifth country regarding the number of planted macadamia trees and the seventh regarding production due to the fact that such plants are young if compared to countries such as Australia and Hawaii, the largest producers. Approximately $70-80 \%$ of the national production of macadamia nuts is intended for export mainly due to the lack of Brazilian consumers (ASSOCIAÇÃO BRASILEIRA DE NOZ MACADÂMIA, 2005).
Macadamia can be considered one of the finest nuts in the world. It has a delicate taste and texture and multiple uses (BUENO, 2009). It can be consumed fresh or as processed foods such as cakes, cookies, chocolates and ice cream (STEPHENSON, 2005). Its oil can be extracted and used in the cosmetic industry as a basis for the manufacture of creams, soap and moisturizers (TOLEDO PIZA, 2000).

The process of spreading macadamia nuts is performed by seeds, forming both ungrafted seedlings and rootstock. However, it has been suggested that graft propagation is more economically advantageous (ANDERSEN et al., 1979; CANN, 1965).

However, the time between seed germination and formation of rootstocks can be more than 120 days after sowing. In this sense, the use of plant growth regulators may be an alternative to reduce the time required for the production of seedling, which is 18 months on average.

With the discovery of the effects of regulators on crops and the benefits provided by these substances, many compounds and combinations of them have been studied aiming to 
improve qualitatively and quantitatively crop yields (VIEIRA, 2001).

Auxins have a characteristic action on cell growth. They act directly by increasing the plasticity of cell walls providing an irreversible stretch. The gibberellic acid has a marked effect on the seed germination process, activating the synthesis of hydrolytic enzymes that operate in the deployment of reserve substances. It also induces cell elongation and cell division. Since cytokinins have a great ability to promote cell division, they participate in elongation and differentiation processes, especially when interacting with auxins (VIEIRA; MONTEIRO, 2002).

According to Davies (2004), plant regulatory substances may act alone or in combination, promoting, inhibiting or modifying physiological and morphological processes of plants. These compounds have been used in various crops such as grapes, soybeans, orange, mango and beans (VIEIRA; CASTRO, 2004).

Arteca (1995) states that germination can be defined as a series of events that occur when a seed is soaked into water, resulting in an increased metabolic activity and provoking the emergence of the embryo. For this process to happen, seed viability and appropriate environmental conditions should be considered (availability of water, proper temperature, oxygen, and, in some cases, the effect of light).

The present study aimed to study the effect of the application of plant growth regulators and shading on the emergence of ALOHA 10-14 macadamia used as rootstock and improve the physiological conditions of the plant.

\section{MATERIAL AND METHODS}

The experiment was conducted in a macadamia seedling nursery of the Macadamia QueenNut company at the farm "Palmeiras" in Dois Córregos, central region of São Paulo. The city is located at $22^{\circ} 22^{\prime} \mathrm{S}$ and $48^{\circ} 20^{\prime} \mathrm{W}$ at $650 \mathrm{~m}$ asl, with an average annual temperature of $25^{\circ} \mathrm{C}$, relative humidity of $70 \%$ and rainfall of $1,250 \mathrm{~mm}$.

The seeds of the species $M$. integrifolia, cultivar ALOHA 10-14, used as rootstock, were collected from a commercial orchard with approximately 14 years of age. The seeds were collected after natural fall, that is, on the floor, and taken to remove the carpel. After weighing, the result was approximately 153 seeds per kilo.

The treatments were T1: water (control under Sombrite $^{\circledR}$ - shade cloth), T2: $\mathrm{GA}_{4+7}+\mathrm{N}$ (phenylmethyl)-aminopurine (Promalin ${ }^{\circledR}$ ) $200 \mathrm{~mL} \mathrm{~L}^{-}$
1, T3: Promalin ${ }^{\circledR} 400 \mathrm{~mL} \mathrm{~L}{ }^{-1}, \mathrm{~T} 4: \mathrm{GA}_{3}+\mathrm{IBA}+\mathrm{Kt}$ (Stimulate $^{\circledR}$ ) $5 \mathrm{~mL} \mathrm{~kg}^{-1}$ seeds; T5: Stimulate ${ }^{\circledR} 10 \mathrm{~mL}$ $\mathrm{kg}^{-1}$ seeds, and T6: water (control, without Sombrite $^{\circledR}$ ).

Seeds were soaked for 24 hours as normally used in farms. In the $\mathrm{T} 1$ and $\mathrm{T} 6$ treatments, the seeds were soaked in water only. In the T2 and T3 treatments, seeds were soaked in a solution containing Promalin ${ }^{\circledR}$. In the T4 and T5 treatments, after soaking in water, seeds were rinsed, dried and received doses of Stimulate ${ }^{\circledR}$. Seeds were then stirred in a closed vessel to obtain a blend uniformity.

The seeds of the treatments T1, T2, T3, T4 and T5 were sown in sand and covered with a shade cloth (Sombrite ${ }^{\circledR}$ ) at $70 \%$, a practice commonly used. T6 seeds were sown without the shade cloth.

A mixture of $\mathrm{GA}_{4+7}+\mathrm{N}$-(phenylmethyl)aminopurine, contained in the commercial product Promalin $^{\circledR}$, was used. It contained $1.8 \%$ of $\mathrm{GA}_{4}+\mathrm{GA}_{7}$ and $1.8 \%$ of $\mathrm{N}$-(phenylmethyl)aminopurine. The mixture gibberellic acid $\left(\mathrm{GA}_{3}\right)+$ kinetin $(\mathrm{Kt})+$ indole butyiric acid (IBA), contained in the commercial product Stimulate ${ }^{\circledR}$, was used. It contained $90 \mathrm{mg} \mathrm{L}^{-1}$ of Kt, $50 \mathrm{mg} \mathrm{L}^{-1}$ of IBA and 50 $\mathrm{mg} \mathrm{L}^{-1}$ of $\mathrm{GA}_{3}$.

After the treatment, the seeds were dried for one day and sowed in a sand bank $1 \mathrm{~m}$ wide, $15 \mathrm{~m}$ long and $10 \mathrm{~cm}$ deep. Seeds were arranged in a $5 \mathrm{~cm}$ spacing. Seeds were $3 \mathrm{~cm}$ apart. The seeds were covered with a layer of approximately $1 \mathrm{~cm}$ of sand.

In all treatments, the substrate was daily and uniformly moistened. The irrigation system was microsprinkler. The manual removal of weeds was performed when necessary.

The treatments were observed daily. From seedling emergence, evaluations performed by counting seeds and emerged seedlings every two days per treatment began. A seedling that presented cotyledons out of the substrate was considered emerged. With this data, we obtained the average percentage of seedling emergence.

The process of emergence of macadamia seedlings was monitored until 140 days after emergence. After, the process stabilized.

The experiment was completely randomized with nine replications with fifty seeds each treatment. The results were submitted to analysis of variance. To compare means, we used the Tukey test at $5 \%$ probability.

The logistic model, setting as variables seedling and time, was used for the statistical analysis of the data using the procedure "proc nlin" of the software SAS. 


\section{RESULTS AND DISCUSSION}

The emergence of macadamia seedlings is slow. The first seedling emerged at 45 days after sowing, continuing up to 140 days. These results agree with those reported by Ojima et al. (1976) and
Simão (1971), who also evaluated the germination of macadamia seeds.

Figure 1 shows the behavior of macadamia seedling emergence under different treatments. Plant growth regulators and time were related from the eighth day after emergence (DAE) when seedlings emerged in all treatments.

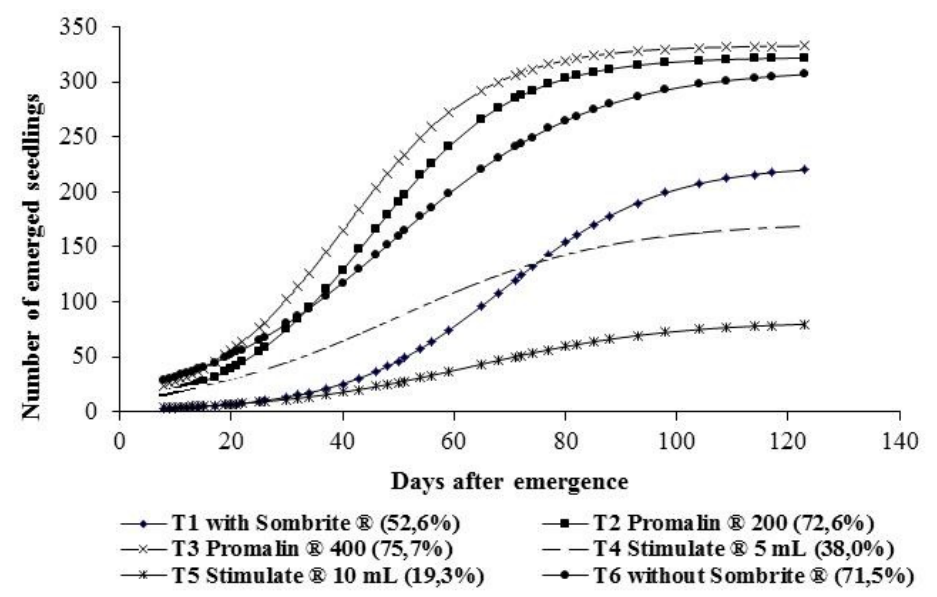

Figure 1. Logistics setting regarding the number of macadamia seedlings (Macadamia integrifolia) emerged after treatment with plant growth regulators in function of time. Dois CórregosSP.

It was found that $\mathrm{T} 3$ provided the highest number of emerged seedlings $\left(\mathrm{GA}_{4+7}+\mathrm{N}-\right.$ (phenylmethyl)-aminopurine (Promalin ${ }^{\circledR}$ ) $400 \mathrm{~mL} \mathrm{~L}^{-}$ 1 with shading), totaling 341 emerged seedlings $(75.7 \%)$. In the $\mathrm{T} 2\left(\mathrm{GA}_{4+7}+\mathrm{N}\right.$-(phenylmethyl)aminopurine (Promalin ${ }^{\circledR}$ ) $200 \mathrm{~mL} \mathrm{~L}^{-1}$ with shading), 327 seedlings emerged $(72.6 \%)$ followed by $\mathrm{T} 6$ (water (control) without shading), with 322 seedlings emerged $(71.5 \%)$.

Consequently, the treatments T2, T3 and T6 showed the best results for percentage of seedling emergence (Figure 1).

The results of the T6 treatment (without shading, control) were very close to treatments with the application of growth regulators. Thus, the mere leaving of seeds exposed to the sun, without protective screens, may increase the percentage of emergence of macadamia seedlings.

The results are similar to those reported by Ono et al. (1996), who studied the application of $\mathrm{GA}_{4+7}+\mathrm{N}$-(phenylmethyl)-aminopurine to macadamia seeds. The authors found an increase in the percentage of germination of treated seeds.

Moreover, these results agree with those found by Ferreira et al. (2002) for Annona squamosa, subsequently verified by Picolotto et al. (2007), regarding the germination of peach seeds. Braga (2008) studied the effects of $\mathrm{GA}_{4+7}+\mathrm{N}-$ (phenylmethyl)-aminopurine on atemoya plants.
Zucareli (2007) also studied the germination of Passiflora cincinnata and found that the growth regulator $\mathrm{GA}_{4+7}+\mathrm{N}$-(phenylmethyl)-aminopurine promotes an increase in germination and emergence and seedling development.

The positive effects of $\mathrm{GA}_{4+7}+\mathrm{N}$ (phenylmethyl)-aminopurine on macadamia seedling emergence was probably due to the action of known gibberellins on seed germination. Such substances may stimulate germination. Consequently, emergence due to the formation or activation of enzymes involved in the breakdown of reserves contained in the seeds provides the embryo with such reserves. This stimulates the growth thereof. On the other hand, cytokinins may have acted in cell division stimulating the growth of seedlings. Taiz and Zeiger (2009) reported that the germination of seeds may require gibberellins for the activation of the embryo vegetative growth or the breakdown of the endosperm layer surrounding the embryo, restricting its growth by mobilizing energy reserves in the endosperm.

According to Coll et al. (2001), factors such as light, temperature and other hormones influence the levels of gibberellins in plants.

The result obtained for the T6 treatment (water without shading) may be associated with the presence of light and the interference of temperature. It is known that such environmental factors influence speed, uniformity and total number 
of germinated seeds (CARVALHO; NAKAGAWA, 2012). Ferraz-Grande and Takaki (2006) reported that the response or sensitivity of seeds to light is specific to each species.

The response to light varies depending on the species. It may photoblastic positive, negative or neutral. The phytochrome is thus responsible for obtaining light signals that will or will not trigger the germination of seeds (CASAL; SANCHÉZ, 1998; FERREIRA; BORGETTI, 2004). The promotion or inhibition of germination by light is the result of a photo-reversible chemical reaction controlled by the phytochrome, a protein-based pigment found in plants in two interconvertible forms. The exposure of seeds to red light $(660 \mathrm{~nm})$ transforms the phytochrome into its biologically active form and germination occurs. The absorption of far-red light $(730 \mathrm{~nm})$ transforms the phytochrome into the red phytochrome form and germination is blocked (TAIZ; ZEIGER, 2009).

According to the results of this study, it is proposed that light, temperature and use of gibberellins may encourage the emergence of macadamia seedlings. The best results were obtained with these variables. We can then propose to the producer planting seedlings without using a shade cloth as an alternative to encourage the emergence and avoid unnecessary production costs and the additional use of a regulated Promalin ${ }^{\circledR}$ product for macadamia.

In $\mathrm{T} 4$ and $\mathrm{T} 5$ treatments, which used $\mathrm{GA}_{3}$ regulators + IBA + Kt $\left(\right.$ Stimulate $\left.^{\circledR}\right)$ and 5 to $10 \mathrm{~mL}$ $\mathrm{kg}^{-1}$ of seeds, respectively, there were lower emergence rates. A higher dose of the same product $\left(10 \mathrm{~mL} \mathrm{~kg} \mathrm{~kg}^{-1}\right.$ of seeds) resulted in the lowest percentage of emergence obtained throughout the experiment. Probably, such results were obtained due to the presence of the Stimulate ${ }^{\circledR}$ product (auxin), since root growth is strongly inhibited by high concentrations of auxin perhaps because auxins induce the production of ethylene, an inhibitor of root growth (TAIZ; ZEIGER, 2009).

These results contradict those found by Prado Neto et al. (2007) studying genipap. In contrast, the results agree with those found by Braga (2008) studying the application of plant growth regulators on the seed germination of atemoya.

According to Vieira and Castro (2004), the germination process requires an active participation of the complex machinery of cell synthesis, which consists of a series of enzymes, factors, cofactors, hormonal substances such as gibberellin, auxin and cytokinin, nucleic acids and other factors still little known, to provide the energy required for the several germination activities.

\section{CONCLUSIONS}

The best results for the emergence of seedlings of the cultivar ALOHA 10-14 $M$. integrifolia, aiming the precocity and the improvement of the physiological conditions of plants, were obtained with the treatment $\mathrm{GA}_{4+7}+\mathrm{N}-$ (phenylmethyl)-aminopurine $400 \mathrm{~mL} \mathrm{~L}^{-1}$.

It is recommended the macadamia seeds be planted in flower beds under a full sun as to stimulate seedling emergence and avoid the use of a shade cloth.

RESUMO: Este estudo objetivou avaliar os efeitos de reguladores vegetais e sombreamento na emergência de plântulas de macadâmia. O experimento foi conduzido no viveiro de produção de mudas de macadâmia da empresa QueenNut Macadâmia, na Fazenda Palmeiras no município de Dois Córregos-SP. Os tratamentos utilizados foram: T1.

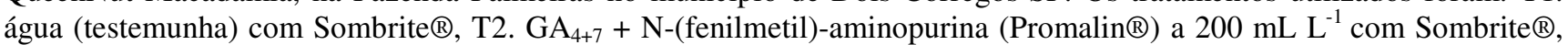

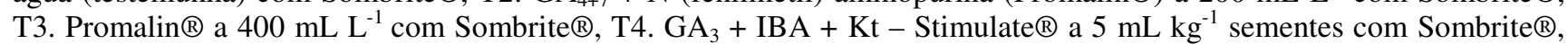
T5. Stimulate ${ }^{\circledR}$ a $10 \mathrm{~mL} \mathrm{~kg}^{-1}$ sementes com Sombrite ${ }^{\circledR}$ e T6. água (testemunha) sem Sombrite ${ }^{\circledR}$. As sementes foram embebidas em água ou nas soluções contendo os reguladores vegetais durante $24 \mathrm{~h}$, secas à sombra e semeadas em sementeiras de areia. Foram utilizadas 450 sementes em cada tratamento. A partir da emergência das plântulas foram iniciadas as avaliações, realizadas através da contagem do número total de plântulas emergidas por tratamento. Os melhores resultados na emergência de plântulas de macadâmia foram obtidos nos tratamentos com $\mathrm{GA}_{4+7}+\mathrm{N}-($ fenilmetil)aminopurina (Promalin $®)$ a $400 \mathrm{~mL} \mathrm{~L}^{-1} \mathrm{com}$ Sombrite $\AA(75,7 \%), \mathrm{GA}_{4+7}+\mathrm{N}$-(fenilmetil)-aminopurina (Promalin $\left.\AA\right)$ a 200 $\mathrm{mL} \mathrm{L}^{-1}(72,6 \%)$ com Sombrite $®$ e água (testemunha) sem Sombrite® $(71,5 \%)$.

PALAVRAS CHAVE: Macadamia integrifolia. Giberelinas. Citocininas.

\section{REFERENCES}

ANDERSEN, O.; RUBENS, V. R.; PINHEIRO, U. F. V. Enxertia da macadâmia (Macadamia integrifolia). In: CONGRESSO BRASILEIRO DE FRUTICULTURA, 5., Pelotas, 1979. Anais... Pelotas, 1979. p. 101-108. 
ARTECA, R. D. Plant growth substances: principles and applications. New York: Chapman \& Hall, 1995. 332 p.

ASSOCIAÇÃO BRASILEIRA DE NOZ MACADÂMIA. Programa Brazilian Macadamia Export. Boletim informativo. Dois Córregos, 2005. (Trabalho não publicado).

BITTENCOURT, P. V. C. Instruções preliminares para a cultura da nogueira-macadâmia. Campinas: Instituto Agronômico, 1965. 12p. (Boletim 162).

BRAGA, J. F. Reguladores vegetais na germinação de sementes e desenvolvimento de plantas de atemóia (Annona cherimoia Mill. x Annona squamosa L.) cv Gefner. 2008. 80f. Tese (Doutorado em Ciências Biológicas) - Instituto de Biociências, Universidade Estadual Paulista, Botucatu, 2008.

BUENO, S. C. S. Macadâmia a noz da longevidade. São Paulo: Coordenadoria de Assistência Técnica Integral (CATI), 2009. Disponível em http: <www.cati.sp.gov.br>. Acesso em: 21 jan. 2009.

CANN, H. J. The macadamia - Austrália's own nut. Agricultural Gazette of New South Wales, v. 76, p. 7884, 1965.

CARVALHO, N. M.; NAKAGAWA, J. Sementes: ciência, tecnologia e produção. 5.ed. Jaboticabal: FUNEP, 2012. 590p.

CASAL, J. J.; SÁNCHES, R. A. Phytochromes and seed germination. Seed Science Research, v. 8, p. 317329, 1998. http://dx.doi.org/10.1017/S0960258500004256

COLL, J. B.; RODRIGO, G. N.; GARCIA, B. S.; TAMÉS, R. S. Fisiologia vegetal. Madrid: Ediciones Pirâmide, 2001. 662p.

DAVIES, P. J. Plant hormones: biosynthesis, signal transduction, action. 3.ed. Dordrecht: Kluwer Academic Publishers, 2004. 750p.

DIERBERGER, J.E.; MARINO NETO, L. Noz Macadâmia - Uma nova opção para a fruticultura brasileira. São Paulo. Editora Nobel, 1985. 120p.

FERRAZ-GRANDE, F. G. A.; TAKAKI, M. Efeitos da luz, temperatura e estresse de água na germinação de sementes de Caesalpinia peltophoroides Benth. (Caesalpinoideae). Bragantia, v. 65, p. 37-42, 2006. http://dx.doi.org/10.1590/S0006-87052006000100006

FERREIRA, G.; ERIG, P. R.; MORO, E. Uso de ácido giberélico em sementes de fruta-do-conde (Annona squamosa L.) visando à produção de mudas de diferentes embalagens. Revista Brasileira de Fruticultura, Jaboticabal, v. 24, n. 1, p. 178-182, 2002.

FERREIRA, A. G.; BORGHETTI, F. Germinação: do básico ao aplicado. Porto Alegre: Artmed, 2004. 323p.

OJIMA, M.; DALL ORTO, F. A. C.; RIGITANO, O. Estudos sobre alguns aspectos da germinação das sementes da nogueira macadâmia. In: CONGRESSO BRASILEIRO DE FRUTICULTURA, 3., Florianópolis, 1976. Anais... Florianópolis, 1976, v. 2, p. 559-566.

OJIMA, M.; DALL’ORTO, F. A. C.; TOMBOLATO, A. F. C.; RIGITANO, O.; VEIGA, A. A.; SABINO, J. C.; PINHEIRO, J. Resultados experimentais de propagação da noz macadâmia no Instituto Agronômico de Campinas, SP. In: CONGRESSO BRASILEIRO DE FRUTICULTURA, 7., Florianópolis, 1983. Anais... Florianópolis, 1983. p. 1038-1053. 
ONO, E. O.; RODRIGUES, J. D.; PINHO, S. Z.; NAKAGAWA, J.; SABINO, J. C. Ação de fitorreguladores e $\mathrm{KNO}_{3}$ na germinação de sementes de macadâmia (Macadamia integrifolia Maiden \& Betche). Científica, v. 24, n. 1, p. 47-54, 1996.

PICOLOTTO, L.; BIANCHI, V. J.; FACHINELLO, J. C. Ação de giberelinas na germinação de sementes de pessegueiro. Scientia Agraria, v. 8, n. 3, p. 225-232, 2007. http://dx.doi.org/10.5380/rsa.v8i3.9526

PRADO NETO, M.; DANTAS, A. C. V. L.; VIEIRA, E. L. ALMEIDA, V. O. Germinação de sementes de jenipapeiro submetidas à pré-embebição em regulador e estimulante vegetal. Ciência e Agrotecnologia, v. 31, n. 3, p. 693-698, 2007. http://dx.doi.org/10.1590/S1413-70542007000300014

SIMÃO, S. Manual de fruticultura. São Paulo: Ceres, 1971. 760p.

STEPHENSON, R. Macadamia: domestication and commercialisation. Chronica Horticulturae, v. 45, n. 2, p. $11-15,2005$.

TAIZ, L.; ZEIGER, E. Fisiologia vegetal. Porto Alegre: Artmed, 2009. 819p.

TOLEDO PIZA, P. L. B. Secagem e escoamento da noz macadâmia (M. integrifolia) em silo secador de fundo cônico. 2000. 84f. Dissertação (Mestrado em Agronomia/Energia na Agricultura) - Faculdade de Ciências Agronômicas, Universidade Estadual Paulista, Botucatu, 2000.

VIEIRA, E. L. Ação de bioestimulante na germinação de sementes, vigor de plântulas, crescimento radicular e produtividade de soja (Glycine $\max$ (L.) Merrill), feijoeiro (Phaseolus vulgaris L.) e arroz (Oryza sativa L.). 2001. 122f. Tese (Doutorado em Agronomia) - Escola Superior de Agricultura "Luiz de Queiroz", Universidade de São Paulo, Piracicaba, 2001.

VIEIRA, E. L.; CASTRO, P. R. C. Ação de bioestimulante na cultura da soja (Glycine max (L.) Merrill). Cosmópolis: Stoller do Brasil, 2004. 74p.

VIEIRA, E. L.; MONTEIRO, C. A. Hormônios vegetais. In: CASTRO, P. R. C.; SENA, J. O. A.; KLUGE, R. A. M. Introdução à fisiologia do desenvolvimento vegetal. Maringá: Eduem, 2002. p. 79-104.

ZUCARELI, V. Germinação de sementes de Passiflora cincinnata Mast.: fases, luz, temperatura e reguladores vegetais. 2007. 103f. Dissertação (Mestrado em Ciências Biológicas) - Instituto de Biociências, Universidade Estadual Paulista, Botucatu, 2007. 